\title{
PRODUCTION OF CARBON DIOXIDE IN VITRO BY BLASTOCYSTS FROM INTACT AND OVARIECTOMIZED MICE
}

\author{
G. A. TORBIT AND H. M. WEITLAUF \\ Department of Anatomy, University of Oregon Medical School, \\ Portland, Oregon 97201, U.S.A.
}

(Received 2nd May 1974)

\begin{abstract}
Summary. 'Normal' and 'delayed implanting' mouse blastocysts were incubated in non-radioactive culture medium for various lengths of time (preincubation), and then placed in culture medium with $\left[{ }^{14} \mathrm{C}\right]-$ glucose for $2 \mathrm{hr}$. The rate of embryonic $\mathrm{CO}_{2}$ production was estimated from ${ }^{14} \mathrm{CO}_{2}$ given off by the blastocysts. Normal embryos were unaffected by the length of preincubation. By contrast, 'delayed implanting' embryos had a low level of $\mathrm{CO}_{2}$ production with short preincubations (i.e. less than $2 \mathrm{hr}$ ), but approached the normal range with longer preincubations (i.e. more than $8 \mathrm{hr}$ ) and thus, were 'activated' in vitro. Incubation of the 'delayed implanting' embryos with actinomycin $\mathrm{D}$ prevented the expected increase in $\mathrm{CO}_{2}$ production, indicating that synthesis of new RNA is necessary for their activation. Preincubation of normal and 'delayed implanting' blastocysts with oestradiol-17 $\beta$ and/or progesterone had no effect on the level of $\mathrm{CO}_{2}$ production, suggesting that the hormones do not directly stimulate or inhibit carbohydrate metabolism in the embryos.
\end{abstract}

\section{INTRODUCTION}

The production of $\mathrm{CO}_{2}$ by mouse blastocysts in the prolonged free-living phase associated with delayed implantation is lower than that by embryos preparing to implant at the normal time (Menke \& McLaren, 1970; Menke, 1972). The difference in rates of $\mathrm{CO}_{2}$ production by 'normal' and 'delayed implanting' embryos appears to be related to maternal levels of oestrogen and progesterone. Thus, in ovariectomized mice given a combination of oestradiol-17 $\beta$ and progesterone, $\mathrm{CO}_{2}$ production by the blastocysts increases to near normal levels but following injection of either hormone alone it remains low. (Torbit \& Weitlauf, 1974). The mechanisms by which maternal hormones regulate embryonic $\mathrm{CO}_{2}$ production, and presumably aerobic metabolism, is not known. Two possible explanations are that the hormones stimulate metabolism by direct interaction with the embryos, or act indirectly by altering the uterine environment (McLaren, 1973).

The present experiments were undertaken to distinguish between these two 
possibilities by incubating 'normal' and 'delayed implanting' embryos in vitro with various concentrations of oestradiol-17 $\beta$ and/or progesterone and measuring the effect on embryonic $\mathrm{CO}_{2}$ production.

\section{MATERIALS AND METHODS}

Sexually mature, virgin, white Swiss mice at random stages of the oestrous cycle were induced to ovulate with injections of gonadotrophins (Fowler \& Edwards, 1957). The females were placed with fertile males and mating was confirmed by the presence of a vaginal plug on the following morning (Day 1 of pregnancy). Pregnant females were allotted to two groups: those in the first group were left intact; those in the second group were ovariectomized before 12.00 hours on Day 4 to prevent implantation (Weitlauf \& Greenwald, 1968) and were injected daily with either sesame seed oil $(0 \cdot 1 \mathrm{ml}$ subcutaneously, Days 7 to 10 , Group 2a) or progesterone $(2.0 \mathrm{mg}$ in sesame seed oil, Days 7 to 10, Group 2b; see Table 1). Blastocysts were collected from intact animals on Day 5 and from ovariectomized animals on Day 10 (09.00 to 10.00 hours) by flushing excised uteri with a stream of culture medium (Brinster \& Thomson, 1966) injected through a blunt needle. Embryos from each group were pooled in $100 \mu \mathrm{l}$ medium in a Maximov slide.

The blastocysts were maintained in non-radioactive medium at $37^{\circ} \mathrm{C}$ in an atmosphere of $5 \% \mathrm{CO}_{2}$ in air for various lengths of time (preincubation period). Batches of fifteen to twenty embryos were then placed in medium with $\left[{ }^{14} \mathrm{C}\right]-$ glucose $(1 \mathrm{mg} / \mathrm{ml}$; sp. act. $3.0 \mathrm{mCi} / \mathrm{mmol}$ : Amersham/Searle) for $2 \mathrm{hr}$ and the rate of $\mathrm{CO}_{2}$ production was estimated by the method of Brinster (1967) as modified by Torbit \& Weitlauf (1974).

In a second experiment, embryos from intact and ovariectomized animals were preincubated in non-radioactive medium with either no hormone, oestradiol-17 $\beta$, and/or progesterone (see Table 2). Following a preincubation period of $4 \mathrm{hr}$, the embryos were recovered and washed three times in fresh medium without steroids. They were then incubated without hormones in radioactive medium for $2 \mathrm{hr}$ to determine the rate of $\mathrm{CO}_{2}$ production.

In a third experiment, 'normal' and 'delayed implanting' embryos were preincubated in medium with actinomycin $\mathrm{D}(10 \mu \mathrm{g} / \mathrm{ml}$; actinomycin $\mathrm{D}$, Sigma Batch Number A-4262) for $8 \mathrm{hr}$ and transferred to radioactive medium without actinomycin $\mathrm{D}$ for $2 \mathrm{hr}$ to determine the rate of $\mathrm{CO}_{2}$ production.

The experiments were carried out over a period of several weeks; experimental trials were conducted on embryos from each group at randomly selected intervals to avoid systematic errors. Statistical differences were determined by use of Newman-Keuls' multiple range test (Steel \& Torrie, 1960).

\section{RESULTS}

The rate of $\mathrm{CO}_{2}$ production by 'normal' blastocysts was unchanged by preincubations of $0,4,8$ or $24 \mathrm{hr}$, indicating that the conditions employed in vitro did not significantly stimulate or inhibit the embryos (Table 1, Group 1). By contrast, production of $\mathrm{CO}_{2}$ by 'delayed implanting' blastocysts increased with 
Table 1. Production of $\mathrm{CO}_{2}$ in vitro by blastocysts from intact and ovariectomized mice

\begin{tabular}{|c|c|c|c|}
\hline Treatment group & $\underset{\text { preincubation }}{\text { Time of }}(h r)$ & pmol $\mathrm{CO}_{2} / e m b r y o / h r$ & $\begin{array}{l}\text { Preincubation medium } \\
\text { changed at } 8 \mathrm{hr}\end{array}$ \\
\hline 1. Intact mice & $\begin{array}{r}0 \\
4 \\
8 \\
24\end{array}$ & $\begin{array}{l}7 \cdot 65 \pm 0.30(12)^{a} \\
7.28 \pm 0.33(10)^{a} \\
7.34 \pm 0.52(10)^{a} \\
6.75 \pm 0.43(12)^{a, e}\end{array}$ & \\
\hline $\begin{array}{l}\text { 2. Ovariectomized mice } \\
\text { a. Oil-treated } \dagger\end{array}$ & $\begin{array}{r}0 \\
4 \\
8 \\
24\end{array}$ & $\begin{array}{l}1.87 \pm 0.16(13)^{b, d} \\
2 \cdot 33 \pm 0.19(11)^{b, d} \\
5.67 \pm 0.45(14)^{c} \\
5.54 \pm 0.40(12)^{\mathrm{c}, \mathrm{e}, \mathrm{b}}\end{array}$ & $5.92 \pm 0.86(4)^{\circ}$ \\
\hline b. Progesterone-treated $\ddagger$ & $\begin{array}{r}0 \\
4 \\
8 \\
24\end{array}$ & $\begin{array}{l}1.58 \pm 0.16(12)^{d} \\
1.86 \pm 0.20(12)^{d, f} \\
2.15 \pm 0.20(10)^{f} \\
3.54 \pm 0.39(15)^{z, h}\end{array}$ & $4 \cdot 78 \pm 0 \cdot 24(7)^{e, h}$ \\
\hline
\end{tabular}

Values are expressed as Mean \pm S.E. and those with different superscripts are significantly different $(P<0.01)$. Figures in parentheses are the number of samples.

* Preincubation in non-labelled medium; followed by $2 \mathrm{hr}$ incubation in medium with $\left[{ }^{14} \mathrm{G}\right]$ glucose; see text for details.

† Ovariectomized on Day 4, and given sesame seed oil subcutaneously on Days 7 to 10.

‡ Ovariectomized on Day 4 , and given progesterone (2 mg) in sesame seed oil subcutaneously on Days 7 to 10 .

Table 2. Production of $\mathrm{CO}_{2}$ by mouse blastocysts incubated with oestradiol-17 $\beta$ and/or progesterone

\begin{tabular}{|c|c|c|c|}
\hline \multirow{2}{*}{$\begin{array}{c}\text { Hormone } \\
\text { in medium* }\end{array}$} & \multirow{2}{*}{$\begin{array}{c}\text { 'Normal' Day-5 } \\
\text { blastocysts }\end{array}$} & \multicolumn{2}{|c|}{$\begin{array}{c}\text { 'Delayed implanting' } \\
\text { blastocysts }\end{array}$} \\
\hline & & $\begin{array}{l}\text { Progesterone } \\
\text { treatment } \dagger\end{array}$ & Oil treatment $\ddagger$ \\
\hline None & $7 \cdot 76 \pm 0 \cdot 13(5)^{a}$ & $1.50 \pm 0.35 \quad(9)^{b}$ & $1.81 \pm 0.09(2)^{b}$ \\
\hline $\begin{array}{c}\text { Oestradiol-17 } \\
1 \times 10^{-10} \mathrm{M} \\
1 \times 10^{-9} \mathrm{M} \\
1 \times 10^{-8} \mathrm{M} \\
1 \times 10^{-7} \mathrm{M} \\
1 \times 10^{-6} \mathrm{M}\end{array}$ & $\begin{array}{c}7 \cdot 29 \pm 0.36(3)^{\mathrm{a}} \\
= \\
7 \cdot 78 \pm 0 \cdot 22(5)^{\mathrm{a}}\end{array}$ & $\begin{array}{l}1.46 \pm 0.11 \quad(9)^{\mathrm{b}} \\
1.90 \pm 0.20(3)^{\mathrm{b}} \\
1.49 \pm 0.22(2)^{\mathrm{b}} \\
1.97 \pm 0.29(4)^{\mathrm{b}} \\
1.98 \pm 0.15(11)^{\mathrm{b}}\end{array}$ & $\begin{array}{c}1.89 \pm 0.08(5)^{b} \\
1.69 \pm 0.07(5)^{b} \\
= \\
1.78 \pm \overline{0.17}(2)^{b}\end{array}$ \\
\hline $\begin{array}{l}\text { Progesterone } \\
\qquad 1 \times 10^{-7} \mathrm{M}\end{array}$ & $7 \cdot 46 \pm 0.26(3)^{a}$ & $1 \cdot 70 \pm 0.22$ & - \\
\hline $\begin{array}{c}\text { Progesterone } \\
1 \times 10^{-7} \mathrm{M} \\
+ \\
\text { Oestradiol-17 } \beta \\
1 \times 10^{-10} \mathrm{M}\end{array}$ & $7.41 \pm 0.58(3)^{2}$ & $1.98 \pm 0.17(13)^{b}$ & - \\
\hline
\end{tabular}

Values are given as pmol $\mathrm{CO}_{2} / \mathrm{embryo} / \mathrm{hr} \pm \mathrm{S}$.E. and those with different superscripts are significantly different $(P<0 \cdot 01)$. Figures in parentheses are the number of samples.

* Preincubated in steroid medium for $4 \mathrm{hr}$; followed by $2 \mathrm{hr}$ incubation in medium with $\left[{ }^{14} \mathrm{C}\right]$ glucose; see text for details.

† Ovariectomized on Day 4, and given progesterone (2 $\mathrm{mg}$ ) in sesame seed oil on Days 7 to 10 .

$\ddagger$ Ovariectomized on Day 4 , and given sesame seed oil $(0.1 \mathrm{ml})$ on Days 7 to 10 . 
preincubations of $8 \mathrm{hr}$ or longer (Group 2a, b). Although $\mathrm{CO}_{2}$ production by embryos from both the oil-treated and the progesterone-treated animals increased with time, the pattern in the two treatment groups was different; thus, the rate of $\mathrm{CO}_{2}$ production by embryos from mice treated with oil increased to near normal levels by 8 to $24 \mathrm{hr}$ (Group 2a), while that of embryos from mice treated with progesterone increased more slowly and did not reach the normal level by $24 \mathrm{hr}$ (Group $2 \mathrm{~b}$ ).

The possibility that activation of embryos from the mice pretreated with progesterone might be retarded by an inhibitory factor carried over with the embryos was tested by transferring the blastocysts to fresh preincubation medium at $8 \mathrm{hr}$ and determining the rate of $\mathrm{CO}_{2}$ production at $24 \mathrm{hr}$. There was no effect on $\mathrm{CO}_{2}$ production by embryos from oil-treated animals; however, a small further increase in the rate of $\mathrm{CO}_{2}$ production by embryos from the progesterone-treated animals was observed (see Table 1). Although this increase was statistically not significant $(P>0.05)$, the rate of $\mathrm{CO}_{2}$ production after changing the medium was comparable to that of normal embryos at 24 hr.

Table 3. Effect of actinomycin $\mathrm{D}$ on $\mathrm{CO}_{2}$ production by 'normal' and 'delayed implanting' mouse embryos in vitro

\begin{tabular}{|c|c|c|c|}
\hline Treatment group & $\begin{array}{l}\text { Preincubation } \\
\text { medium without } \\
\text { actinomycin D }\end{array}$ & $\begin{array}{l}\text { Preincubation } \\
\text { medium with } \\
\text { actinomycin } D^{*}\end{array}$ & $\mathbf{P}$ \\
\hline $\begin{array}{l}\text { Intact mice } \\
\text { Ovariectomized mice } \dagger\end{array}$ & $\begin{array}{l}7.30 \pm 0.59(7) \\
5.63 \pm 0.38(5)\end{array}$ & $\begin{array}{l}5 \cdot 29 \pm 0.24 \\
1 \cdot 07 \pm 0.12(16)\end{array}$ & $\begin{array}{l}<0.01 \\
<0.01\end{array}$ \\
\hline
\end{tabular}

\footnotetext{
Values are given as pmol $\mathrm{CO}_{2} / \mathrm{embryo} / \mathrm{hr} \pm$ S.E. Figures in parentheses are number of samples.

* Preincubated for $8 \mathrm{hr}$ in medium with actinomycin D (10 $\mu \mathrm{g} / \mathrm{ml})$; followed by $2 \mathrm{hr}$ incubation in medium with $\left[{ }^{14} \mathrm{C}\right]$ glucose.

† Ovariectomized on Day 4, and given sesame seed oil $(0.1 \mathrm{ml})$ on Days 7 to 10 .
}

The possibility that progesterone carried over with the embryos might be responsible was tested by preincubating 'normal' and 'delayed implanting' embryos directly with progesterone (Table 2). Progesterone in the preincubation medium had no significant effect on the rate of $\mathrm{CO}_{2}$ production by either 'normal' or 'delayed implanting' embryos. Furthermore, incubation of 'normal' or 'delayed implanting' embryos in various concentrations of oestradiol or oestradiol + progesterone had no significant effect on $\mathrm{CO}_{2}$ production.

Preincubation of 'delayed implanting' embryos in actinomycin D for $8 \mathrm{hr}$ completely inhibited the expected increase in $\mathrm{CO}_{2}$ production (Table 3); although incubation of 'normal' embryos with actinomycin $\mathrm{D}$ resulted in a significantly reduced rate of $\mathrm{CO}_{2}$ production $(P<0.01)$, the change was small compared to that in 'delayed implanting' embryos.

\section{DISCUSSION}

The present results confirm the observation of Menke \& McLaren (1970) that 'delayed implanting' mouse blastocysts have low levels of $\mathrm{CO}_{2}$ production. 
Furthermore, it is shown that the rate of $\mathrm{CO}_{2}$ production by 'delayed implanting' mouse blastocysts in vitro increases from characteristically low levels immediately after the embryos are removed from the uterus to levels near those for normal blastocysts after 8 to $24 \mathrm{hr}$ in vitro (Table 1, compare Groups 1 and 2). A similar activation of 'delayed implanting' blastocysts has been reported to occur in vivo only in the presence of oestrogen and progesterone (Torbit \& Weitlauf, 1974); it was found in the present experiments that the hormones are not required in vitro.

Menke \& McLaren (1970) reported that the level of $\mathrm{CO}_{2}$ production by delayed implanting blastocysts from animals treated with progesterone is significantly below that by embryos from animals given no treatment; the present results did not confirm that observation. The explanation for the discrepancy may be related to the different lengths of incubation in radioactive medium used in the two experiments (i.e. 4 versus $2 \mathrm{hr}$ ). The shorter incubation time used in the present study made it possible to observe that the effect of pretreating the mother with progesterone was not to decrease the level of $\mathrm{CO}_{2}$ production by eggs in utero (i.e. $0 \mathrm{hr}$ preincubation) but was rather to reduce the rate at which the embryos became activated.

In attempting to explain the effect on the embryos of giving progesterone to the mother, the preincubation medium was changed at $8 \mathrm{hr} ; \mathrm{CO}_{2}$ production by eggs from the oil-treated animals was not affected, but that of embryos from the progesterone-treated animals increased further. Even though this increase was not statistically significant $(P>0.05)$, the $\mathrm{CO}_{2}$ production by the embryos was comparable to that of 'normal' embryos at $24 \mathrm{hr}$ suggesting the possibility that progesterone or a uterine factor associated with progesterone might have been carried over with the embryos and slowed their activation. It seems unlikely that progesterone per se is responsible since incubation of embryos directly in progesterone had no inhibitory effect on the rate of $\mathrm{CO}_{2}$ production by 'normal' eggs (i.e. in the 4-hr preincubation period used here).

It has been reported that oestrogen stimulates RNA synthesis (Lau, Davis \& Chang, 1973) and protein synthesis in mouse blastocysts in vitro (Smith \& Smith, 1971). With the conditions employed in the present study, we were unable to demonstrate a direct effect of any concentration of oestrogen or oestrogen + progesterone on $\mathrm{CO}_{2}$ production by either 'normal' or 'delayed implanting' embryos.

The mechanism by which 'delayed implanting' embryos are activated has not yet been definitely worked out. Two current explanations are that the embryos are: (1) stimulated directly by hormones or hormone-dependent uterine factors; and (2) that the embryos are de-repressed by removal of an inhibitory uterine factor (see McLaren, 1973, for a recent review). The present results suggest that stimulation of the embryos by direct hormonal action is not essential for their activation. Although it may be argued that the conditions of culture or the medium used in this experiment are stimulatory, this seems unlikely since the medium used in the present experiments does not contain serum or serum fractions and the only macromolecular constituent is crystalline bovine albumin. Bovine albumin does not appear to exert a stimulatory effect since the normal embryos are not affected. 
Psychoyos \& Bitton-Casimiri (1969) suggested that a uterine inhibitor of embryonic RNA transcription may be responsible for the dormant condition of embryos in delayed implantation. Although the present finding that actinomycin D prevents the expected activation of 'delayed implanting' embryos in vitro suggests that new RNA and presumably protein must be synthesized for increased $\mathrm{CO}_{2}$ production to occur, this is not completely clear. The concentration of actinomycin D used $(10 \mu \mathrm{g} / \mathrm{ml})$ had a slight but statistically significant effect on $\mathrm{CO}_{2}$ production by the normal embryos. Although it seems unlikely that non-specific effects of the drug may account for failure of the embryos to become activated, that possibility cannot be ruled out from the present data.

If a uterine factor is responsible for the quiescent condition of embryos in delayed implantation, the present results suggest there is more of it or it is more effective following pretreatment of the mother with progesterone. This may explain the protective effect of progesterone on mouse embryos retained as 'delayed implanting' blastocysts in uteri beyond Day 10 (Weitlauf, 1971).

\section{ACKNOWLEDGMENT}

This work was supported by the A.E.C. (Report COO-1801-34).

\section{REFERENCES}

BRINSTER, R. L. (1967) Carbon dioxide production from glucose by the preimplantation mouse embryo. Expl Cell Res. 47, $271-277$.

BRinster, R. L. \& Thomson, J. L. (1966) Development of eight-cell mouse embryos in vitro. Expl Cell Res. $42,308-315$.

FowLeR, R. E. \& EDWARDs, R. G. (1957) Induction of superovulation and pregnancy in mature mice by gonadotrophins. F. Endocr. 15, 374-384.

LAU, N. I. F., Davis, B. K. \& Chang, M. C. (1973) Stimulation of in vitro ${ }^{3} \mathrm{H}$-uridine uptake and RNA synthesis in mouse blastocysts by $17 \beta$-estradiol. Proc. Soc. exp. Biol. Med. 144, 333-336.

McLaren, A. (1973) Blastocyst activation. In The Regulation of Mammalian Reproduction, pp. 321-328. Eds. S. J. Segal, R. Crozier, P. A. Corfman and P. G. Condliffe. Thomas, Springfield.

Menke, T. M. (1972) Changes in mouse blastocyst carbon dioxide production as a function of time postcoitum in delay of implantation during lactation or following ovariectomy. Biol. Reprod. 7, 414-416.

Menke, T. M. \& McLaren, A. (1970) Carbon dioxide production by mouse blastocysts during lactational delay of implantation or after ovariectomy. F. Endocr. 47, 287-294.

Psychoyos, A. \& Bitton-Casimiri, V. (1969) Captation in vitro d'un précurseur d'acide ribonucléique (ARN) (uridine-5- ${ }^{3} \mathrm{H}$ ) par de blastocyste du rat; différences entre blastocystes normaux et blastocystes en diapause. C. r. hebd. Seanc. Acad. Sci., Paris, 268, 188-190.

SMITH, D. M. \& SMITH, A. E. S. (1971) Uptake and incorporation of amino acids by cultured mouse embryos: estrogen stimulation. Biol. Reprod. 4, 66-73.

Steec, R. G. D. \& Torrie, J. H. (1960) Principles and Procedures of Statistics. McGraw-Hill, New York.

Torbit, C. A. \& WEITLAUf, H. M. (1974) The effect of oestrogen and progesterone on $\mathrm{CO}_{2}$ production by 'delayed implanting' mouse embryos. F. Reprod. Fert. 39, 379-382.

WEITLAUR, H. M. (1971) Effect of progesterone on survival of blastocysts in uteri of ovariectomized mice. 7. Endocr. 51, 375-380.

WeItLAUT, H. M. \& GREENWALd, G. S. (1968) Influence of estrogen and progesterone on the incorporation of ${ }^{35} \mathrm{~S}$ methionine by blastocysts in ovariectomized mice. F. exp. Zool. 169, 463-470. 